\section{1 分子蛍光観察によるセロビオヒドロラーゼの結晶性セル} ロース加水分解反応素過程の解明

Single-molecule imaging analysis of cellobiohydrolase hydrolyzing crystalline cellulose

Yusuke Shibafuji ${ }^{1}$, Akihiko Nakamura $^{2}$, Naohisa Sugimoto ${ }^{2}$, Kiyohiko Igarashi $^{2}$, Shingo Fukuda ${ }^{3}$, Hiroki Watanabe ${ }^{3}$, Takayuki Uchihashi ${ }^{3}$, Hiroyuki Noji ${ }^{1}$, Ryota Iino ${ }^{1}\left({ }^{1}\right.$ Dept. Appl. Chem. Univ. Tokyo, ${ }^{2}$ Dept. Bio. Sci. Univ. Tokyo, ${ }^{3}$ Dept. Phys. Kanazawa Univ)

Cellobiohydrolase is a new type of linear molecular motor that hydrolyzes crystalline cellulose into water-soluble disaccharide at solid/liquid interface. Here, with single-molecule fluorescence microscopy and highspeed AFM, we revealed the adsorption-desorption dynamics and linear translocation of Trichoderma reesei cellobiohydrolase $(\operatorname{Tr} \mathrm{Cel} 7 \mathrm{~A})$ hydrolyzing Type $\mathrm{I}_{\alpha}$ crystalline celluloses. $\operatorname{Tr}$ Cel7A showed binding rate constant of $9.7 \times 10^{6} \mathrm{M}^{-1} \mu \mathrm{m}^{-2} \mathrm{~s}^{-1}$, including productive and non-productive binding that lasted $8.6 \mathrm{~s}$ and $1.2 \mathrm{~s}$ respectively. The velocity of movement on cellulose in the productive binding was $5.0 \mathrm{~nm} / \mathrm{s}^{\left(5 \mathrm{~s}^{-1}\right.}$ in turnover rate). Our results shed light on the enzyme reaction mechanism at solid/liquid interface at the single-molecule level for the first time.

\section{P170 負荷存在下でのキネシン頭部の運動の高時間分解能観察}

High temporal resolution observation of the stepping motion of kinesin-1 under load

Issui Akishika ${ }^{1}$, Ryota Iino $^{2}$, Hiroyuki Noji ${ }^{2}$, Michio Tomishige ${ }^{1}$ ( ${ }^{1}$ Dept Appl. Phys., Grad. Sch. Eng., Univ. Tokyo, ${ }^{2}$ Dept. Appl. Chem., Grad. Sch. Eng., Univ. Tokyo)

Kinesin-1 is a motor protein that walks along microtubules to transport cargoes. The velocity of the movement decreases with increasing load, however it is still unclear which conformational transition is the loaddependent. At the last meeting, Isojima in our lab demonstrated that we could distinguish bound and unbound states of the motor head using darkfield microscopy with $50-\mu$ s temporal resolution. In this study, we constrained the kinesin movement by fusing a mutant head that cannot detach from the microtubule to the stalk of wild-type dimer. Then we observed the movement of a wild-type head, which showed discrete $16 \mathrm{~nm}$ steps and then stalled after several steps. We will discuss the effect of load on the duration of bound and unbound states of a head.

2P171

\section{ジスルフィドクロスリンクを用いたキネシン 1 の二足歩行制 御機構の研究}

Strain-dependent regulation of the kinesin-1's catalytic activity as studied by disulfide-crosslinking of the neck linker

Yamato Niitani ${ }^{1}$, Erik Jonsson ${ }^{2}$, Ronald D.Vale ${ }^{2}$, Michio Tomishige ${ }^{1}\left({ }^{1}\right.$ Dept Appl. Phys., Grad. Sch. Eng., Univ. Tokyo, ${ }^{2}$ Dept. CMP, Univ. California)

Kinesin-1 walks along microtubules by alternately hydrolyzing ATP and moving two motor domains, although the mechanism of the alternate catalysis remains unknown. Here we focused on the neck linker that connects two motor domains and investigated the effect of the neck linker tension on the motor activity by constraining the neck linker in the forward or backward extended conformation using disulfide-crosslinking. Stopped flow and single molecule measurements showed that the forward-constraint of the neck linker reduced ADP release rate although the backwardconstraint suppresses either ATP hydrolysis or Pi release rate. These results suggest that ATP hydrolysis cycle can be differently regulated depending on the direction of the neck linker tension.

\section{SDSL-ESR により検出したキネシン $\alpha-1$ ヘリックスのヌクレ} オチド依存的な動的構造とその变位

Nucleotide-dependent Displacement and Dynamics of $\alpha$-1 Helix in Motor Protein Kinesin As Revealed by Site Directed Spin Labeling ESR

Satoshi Yasuda ${ }^{1}$, Takanori Yanagi ${ }^{1}$, Masafumi Yamada $^{2}$, Shinsaku Maruta ${ }^{2}$, Toshiaki Arata ${ }^{1}$ ( ${ }^{1}$ Dept. Biol. Sci., Grad. Sch. Sci., Osaka Univ., ${ }^{2}$ Soka Univ.)

We show the nucleotide-dependent displacement of the $\alpha-1$ helix of kinesin on microtubule by ESR spectroscopy. Kinesin monomer was doubly spinlabeled at $\alpha-1$ and $\alpha-2$. The inter-helix distance distribution was determined by spectral broadening and showed that $40 \%$ of spins had a peak at 1.4-1.7 $\mathrm{nm}$, which was close to that from crystal structure, but $60 \%$ beyond sensitivity $(>2.5 \mathrm{~nm})$. The fraction of $1.4-1.7 \mathrm{~nm}$ was 20 and $25 \%$ in the presence of AMPPNP and ADP, respectively. These nucleotide-induced decreases in the fraction of 1.4-1.7 $\mathrm{nm}$ were reversely related to those in the docking fraction of neck-linker on motor core, suggesting that shift of spatial equilibrium of $\alpha-1$ helix from 1.4-1.7 nm toward $>2.5 \mathrm{~nm}$ makes its $\mathrm{C}$-terminal end to be exposed and bind neck-linker.

\section{P173微小管上での KIF1A の選択的結合における負に荷電した C 末の役割}

The role of negatively-charged C-terminus of tubulin in selective binding of KIF1A on microtubule

Yukinobu Mizuhara, Jun Ohnuki, Koji Umezawa, Mitsunori Takano (Dept. of Phys. \& Appl. Phys, Grad. Sch. of Adv. Sci. \& Eng. Waseda Univ.)

KIF1A, a well-studied motor protein, functions as a monomer, where the force-generating biased binding to the microtubule (MT) has been observed during the weak-to-strong binding transition. While it is obvious that the weak binding is maintained by the electrostatic interaction between the lysine-rich K-loop of KIF1A and the glutamate-rich C-terminus of tubulin (E-hook), it is less clear why KIF1A selectively binds on the $\alpha-\beta$ tubulin junction within the tubulin dimer rather than the $\beta-\alpha$ junction between the tubulin dimers. In this study, by calculating the binding energy between KIF1A and MT, we investigated the molecular mechanism of the selective binding of KIF1A, which also has close relevance to the biased binding, and show that E-hook plays the key role.
2P174

\section{フォトクロミック分子を用いた有糸分裂キネシン Eg5 の光 制御型阻害剂}

Photo regulted inhibitor composed of photochromic molecules for mitotic kinesin $\mathbf{E g} 5$

Kanako Tohyama ${ }^{1}$, Kumiko Ishikawa ${ }^{2}$, Shinsaku Maruta ${ }^{1,2}\left({ }^{1}\right.$ Div. Bioinfo., Grad. sch. Eng., Univ. Soka, ${ }^{2}$ Dep. Bioinfo., Fac. Eng., Univ. Soka)

S-trityl-L-cysteine (STLC) is a well known specific inhibitor for mitotic kinesin Eg5. Trityl group of STLC is a key moiety to inhibit Eg5 ATPase potently. In this study, we designed and synthesized the photo regulated inhibitors to control Eg5 activity. The photochromic inhibitor 4,4'-bis(N(2-(triphenylmethylamino)acetyl)amino)azobenzene (BTAB) was synthesized. by the coupling reaction of 4,4'-diaminoazobenzene with tritylglycine. And other related inhibitors were also synthesized. BTAB showed cis-trans isomerization upon $380 \mathrm{~nm}$ and $480 \mathrm{~nm}$ light irradiations. BTAB inhibited reversibly Eg5 ATPase activity in the absence of microtubules by light irradiations. We also examined which step along ATPase kinetic pathway is inhibited by BTAB using stopped flow apparatus. 